\title{
Perceptions Regarding the Care and Education of Children from Birth to Age Three among Students of Early Childhood Education: Changes between Pre-training and Post-training
}

\author{
Gila Russo-Zimet ${ }^{1}$, Itzhak Gilat ${ }^{1}$ \\ ${ }^{1}$ Levinsky College of Education, Tel Aviv, Israel \\ Correspondence: Gila Russo-Zimet, Levinsky College of Education, Tel Aviv, Israel.
}

Received: January 5, 2017

doi:10.11114/jets.v5i3.2198

\author{
Accepted: February 3, 2017 \\ Online Published: February 6, 2017 \\ URL: http://dx.doi.org/10.11114/jets.v5i3.2198
}

\begin{abstract}
Many theoreticians focus on understanding the belief system regarding the mind of the learner - The Mind Theory. Olson \& Brunner (1996) referred to this belief system as "folk psychology". They named the processes required to promote learners' knowledge and understanding "folk pedagogy". In their opinion, folk pedagogy reflects the learners' folk psychology. In other words, the study of folk psychology has focused on how everyday people - those without formal training in the various academic fields of science - go about attributing mental states. This domain has primarily been centered on intentional states reflective of an individual's beliefs and desires.

The present study set up to characterize the folk psychology (contains expressions and summaries of various settings as a way of informally shaping quite general meanings or organizing experience) and the folk pedagogy, which deals with where, when and why people teach or educate one another in various ways for the sake of making out of things (Olson \& Bruner, 1996) in early childhood education students with respect to education and care during the first three years of life and examine whether these views change during the course of their formal education.

The sample comprised of 379 students of education majoring in early childhood education at three colleges in Israel. Data was gathered by a structured questionnaire examining five domains: the impact of year of life on child development, domains affecting child development, care and educational settings, care and educational methods and the role of caregivers. The findings reveal that the perceived influence of family care centers and daycare centers influence on child development decreases between the beginning and the end of their studies. The perceived effectiveness of coping through awareness increased, while strict coping methods were perceived as less effective after the training.
\end{abstract}

Keywords: early childhood, education caregivers, teacher education, perceptions

\section{Literature Review}

This study examined students' folk psychology \& pedagogy regarding the education and care of children from birth to age three. Many studies have examined the role of teacher preparation, under the assumption that these teachers have previous perceptions, believes and knowledge, developed over time and that the "learning" begins prior to the formal teacher preparation (Cochran-Smith \& Villegas, 2015; Cochran-Smith, et.al., 2015).

As more and more women enter the workforce, early childhood educational settings multiply as well. A multitude of daycare centers were established to meet this need, though the prevailing approach was that the purpose of these centers was to provide "day care" as opposed to education. In Israel, the Ministry of Education is the public institution thought to be responsible for meeting the educational needs of children from birth to age six, yet its legal responsibility covers only the three-six age range. Responsibility for children from birth to age three, and specifically for the daycare centers, is under the auspices of the Ministry of Industry, Trade and Labor (Tamat) through its Division of Education and Care Centers for Young Children (Tzaban, 2012).

Many factors shape perceptions and viewpoints, and they are both personal and professional (Lee \& Johnson, 2007; Kitayama \& Cohen, 2010). This study focuses on early childhood education students in Israel (Arabs and Jews, religious and secular) as a confederated company in Israel, and examines their folk psychology \& pedagogy regarding the education and care of children from birth to age three. 
Much has been written about children from birth to age three, the most critical age from the psychological, emotional and cognitive perspective; appropriate stimuli, close interaction with loving caregivers, rich verbal environment, opportunities for play facilitating, motoric experience and cognitive stimulation, all enhance the child's development at theses ages. Moreover, studies have shown that investing in children's development at an early age contributes to their later success in school and consequently in society (Campbell, Pungello, Miller-Johnson, Burchinal \& Ramey, 2001; Johansson, Cobb-Moore, Lunn-Brownlee, Walker, Boulton-Lewis \& Ailwood, 2014; Ramey \& Ramey, 2004). Researchers in the US have found that investing in early childhood education yields economic dividends (Chetty, Friedman, Hilger, Saez, Schanzebbach \& Yagan, 2010; Schweinhart \& Fulcher-Dawson, 2009).

Existing literature focusing on the education of young children claims that the importance of the quality of care and education affects these children for the rest of their lives (e.g., DeSchipper, Riksen-Walraven \& Geurts, 2006; Susman-Stillman, Pleuss \& Englund, 2013). It is especially important for the staff working with young children to receive proper training (e.g., Taguma, Litjens \& Makowiecki, 2012; Thorpe, Ailwood, Brownlee \& Boyd, 2011).

Proper training programs, that train students intended to work with children, are a necessary pre-condition for the development of the perceptions and comprehension of the future educational staff members (Darling-Hammond, Wei \& Johnson, 2009; Darling-Hammond \& Haertel, 2012).

\subsection{Early Childhood Education in Israel}

Research literature in the modern world claims that the quality of the educational settings and their contribution to child development are a function of the following: a) the size of the group and the ratio between the number of children and the number of educators/caregivers; b) the level of education and training among the educators/caregivers; c) the work and salary conditions of the educators/caregivers; and, d) the coordination and integration of the educational setting with other services (Deynoot-Schaub \& Riksen-Walraven, 2005; Sroufe, Cooper \& DeHart, 1992).

Whether we study children in the world or in Israel, it is found that high quality education reduces social inequalities. The research literature also found that the correlations between quality education and particularly between the ages of birth to three or more improves cognitive abilities. The review emphasizes the great sensitivity inherent in young ages and the importance of high quality frameworks. Israel has no longitudinal studies as there are in the US or the UK. There are also no intervention programs (The Dovrat Commission Report, 2005).

In Israeli society today, the birth to age three group (three age levels) comprises approximately 500,000 children. Approximately 100,000 are enrolled in non-maternal childcare settings, supervised, and subsidized by the state (Central Bureau of Statistics, 2010). In 2011 an amendment was passed to the Compulsory Education Law (Amendment No. 16), extending compulsory education to ages three to four group. This amendment helped separate the Compulsory Education Law from the Arrangements Law to ensure that children between the ages of three and five would receive free government-supervised education.

In recent years, modernization caused several cultural changes in Israel. The main modern change, which influenced the education of children from birth to age three group, is the increase in the numbers of women in the workforce. This change is influenced by the cultural background in Israel societies, because of the different cultural perceptions. As a result, the number of early childhood educational settings has increased as well, though the level of care has remained much as it was in the past (Espanioly, 2015).

Rosenthal (2009) indicated that, in their present form, daycare centers do not provide a sufficient response to children. The number of hours, which toddlers in Israel spend in daycare centers, is of the highest in the world. Daycare centers are operated by for-profit organizations and local councils. These centers must meet standards set by The Ministry of Economics in regards to the children's group size, the ratio between caregivers and children, and safety issues. There is no binding curricula for daycare centers. A committee that examined the state of education in the country found that about half of the institutions operate without the authorities' permission, are not supervised by the state in terms of safety and hygiene, and are not committed to regulatory standards (Committee for Economic and Social Change, 2011 also known as The Trajtenberg Committee).

In 2011, an amendment was passed to the Compulsory Education Law (Amendment No. 16) extending compulsory education to ages 3-4. This amendment was to serve as a practical tool for implementing the recommendation of the Trajtenberg Committee (2011) regarding preschool education for children aged 3-4. Its goal was to remove the law from the Arrangements Law to prevent it from being postponed and to ensure that children between the ages of three and five would receive free government-supervised education. The law was intended to be enforced completely within three years, beginning in 2012-2013 and no later than 2014-2015. Each year, one-third of the children aged 3-4 would be included in the implementation of the Compulsory Education Law. The Trajtenberg Committee also recommended removing the authority and responsibility for the daycare centers and family home childcare settings from the Minister 
of Industry, Trade and Labor and transferring it to the Minister of Education. One of the reasons for this move was the two-fold aim of expressly recognizing the importance of education from birth to age three and implementing the setting of ongoing and comprehensive educational policy beginning with the early developmental stages (Watamura, Phillips, Morrissey, McCartney \& Bub, 2011).

This is not to imply that the Tamat Ministry has not acted in accordance to the authorities vested in it but rather to reflect the need for a change in organizational structure to assert the importance of the changing perspectives in the field of early childhood. This new law and the committee's recommendations for its early implementation lead to the assumption that the structure and content of the training provided at the colleges of education in the early childhood education programs will also be affected, with more emphasis placed upon the birth-to-three age group.

Moreover, in improving this training, it is important to understand the folk psychology \& pedagogy knowledge the students bring along with them to their studies. This will lead to reinforcing valid approaches and providing them with theoretical support. On the other hand, erroneous approaches should be eliminated, particularly those with no firmly established consensus opinion or scientific basis. Based on the above, it is important to examine students' perceptions regarding the training they currently receive at the colleges of education for the birth-to-three age group.

Studies conducted in Israel (Koren-Karie \& Sagi, 2000; Sagi, Koren-Karie, Gini, Ziv \& Joels, 2002) examined the impact of non-maternal childcare from birth to age three on the child's development. These studies focused on the perceptions of parents and caregivers. Findings of these studies indicate that as long as the child receives personal care from a stable and warm individual the mother's absence does not have a negative impact on the child's emotional development. Group arrangements, such as non-maternal childcare centers, provide a suitable solution only if it meets high quality care standards. These studies suggest maternal child care centers are the less preferred solution for the birth to age three group and are positioned at the bottom of the list when it comes to warm and responsive care. Furthermore, the standards of quality and care in the non-maternal childcare centers, such as the quality of the center and the caregiver-child ratio, influence the emotional development of the children from birth to age three.

The results of these studies are supported by international research literature (e.g., Chetty et.al., 2010; DeSchipper, Riksen-Walraven \& Geurts, 2006; Gunnar, Kryzer, Van Ryzin \& Phillips, 2010; Ispa, 1995; Lunn-Brownlee, Johansson, Cobb-Moore, Boulton-Lewis, Walker \& Ailwood, 2013; Schweinhart \& Fulcher-Dawson, 2009; Susman-Stillman, Pleuss \& Englund, 2013; Theobald, Danby \& Ailwood, 2011; Watamura, Donzella, Alwin \& Gunnar, 2004).

\subsection{Training Educational Staff in Care Centers for Birth to Age Three Group in Israel}

Results of studies conducted over the past twenty years have raised public awareness, as well as government and education officials' awareness, regarding the importance of the "inverted pyramid". This term was coined in the Report of the Task Force for the Advancement of Education in Israel, intended to invest in young ages in order to avoid difficulties in the future - National Education Plan (The Dovrat Commission Report, 2005). This report, which was based on numerous studies and expert opinions in the field of early childhood education, asserted that investing in the youngest age group (0-3) in building children's futures is of a major importance.

This decision compelled the teacher training system to become involved in the educational activities of daycare and family care settings. This raised the question of what, in fact, is good and proper training for those working with the birth-to-three group (Tzaban, 2012).

In Israel, there are two frameworks of daycare teacher instruction. Training of caregivers working with children aged birth to three, who are the main caregivers in daycare centers in the country today. They received their certification only after completing training courses given by the Ministry of Economy. These caregivers were not required to complete 12 years of formal education. The other group includes kindergarten teachers that receive academic training in a college of education in early childhood programs. Today, the age three group is covered by the Israeli education system and the education of students in the various colleges includes birth to age three group as well.

Training for children from birth to age three is given as part of general academic studies towards bachelor's degree in early childhood education and the certificate received after completing these studies is teaching certificate for children from birth to six.

Few studies have examined perceptions of students and instructors in training programs for preschoolers regarding the training programs. In the research literature (Dayan, 2006; Koren-Karie \& Sagi, 2000; Klein, 2008; Rosenthal, 2004), researchers underline the major significance of providing abundant and comprehensive knowledge to staff members. These researchers claim that a highly trained staff will help promote children's cognitive, emotional and social development by means of positive interaction in a constructive and suitable environment.

In teacher education colleges in Israel, the early childhood education programs for preschool teachers provide training for working with children from birth to age three as part of the curriculum for a B.A. in early childhood education. The 
graduates of these programs are certified to teach children from birth through age 6. The Ariav Plan (2007) formulated following the report of the Ariav Committee redefined the age range for which preschool teachers are trained to teach. Before the plan was accepted, preschool teachers were trained to work with the 3-8 age group (including first and second grades), while currently, they are trained to work with the 0-6 age group. The Ariav Plan is intended to train a workforce to work with children from birth to age six based on the view that future preschool teachers should be familiar with child development from its inception.

It should be noted that most of the practice teaching the colleges of education require of their students takes place at preschools for children between the ages of three and six. In their theoretical studies, the students learn the basic theories of child development (Freud, Bowlby, Winnicott, Erikson, Piaget, Vygotsky, Klein, Theory of Mind and others). Teaching practice at daycare centers takes place during their first semester of studies. The colleges have difficulty working with educational settings for children aged 0-3 because of technical reasons, among them problems in coordination with the Tamat Ministry and the private daycare centers and preschools and a lack of high quality settings able to absorb pre-service teachers (Tzaban, 2012).

\subsection{The Perceptions/Attitudes of Early Childhood Education Students Regarding the Care of Young Children}

In literature today, it is acceptable to distinguish between two main groups of variables that the quality of care in early childhood is derived from: a structural quality and process quality. Structure quality refers to inputs, educational framework such as the number of children in the group, the ratio between the number of children and number of caregivers, structure size, education and professional development of educational staff and so on. Process quality refers to the educational process and the caregiving framework: how the children are being addressed, caregiver or teacher-child interactions, and responsiveness to the needs of the child and his wishes and so on (DeSchipper, Riksen-Walraven, \& Geurts, 2006). It is possible to notice a number of characteristics of a high quality education at a young age. The curriculum should relate to these characteristics and therefore it is important to have an in depth examination of the training programs for children from birth to three in colleges of education and examine the perceptions of students and instructors about these properties, in order to plan a more optimal future in this training context.

The findings highlight the importance and the urgent need to raise the prestige and importance of training for children from birth to three. According to the study's participants, there is a misconception in the public's opinion that anyone can take care of children in the birth to three age groups, since no complex care is needed and the caregiving is essentially physical care (feeding, changing diapers, sending the children to sleep, etc.). It is thought that they do not require care that has educational, emotional, social and cognitive aspects, so therefore there is no need for special training and professionalism in order to work with these ages. However, research literature in the fields of child development emphasizes the first three years of a child's life as a critical period for the development of various abilities of the child and of crucial importance to his life (McCormick, Brooks-Gunn, Buka, Goldman, Yu, Salganik, Scott, Bennett, Kay, Bernbaum, Bauer, Martin, Woods, Martin \& Casey, 2006; Mustard, 2007).

Most studies examining students' perceptions and attitudes toward education have been conducted among students of elementary, middle school and high school education (e.g., Decker \& Rimm-Kaufman, 2005; Rimm-Kaufman, Storm, Sawyer, Pianta \& La Paro, 2006). Very few studies have examined the perceptions and attitudes of preschool education students with respect to children discipline, educational methods and behavior. Some have examined preschool educational methods with respect to the type of care recommended for this age group (Ispa, 1995; La Paro, Siepak \& Scott-Little, 2009). The Australian researchers Ailwood \& Boyd (2006) distributed a questionnaire to first-year preschool education students asking them how they feel about children who are in full-day daycare settings (not with their mothers). Respondents expressed negative opinions and feelings about this situation, commenting that it is the parents' responsibility to care for their children, and no one else's and that they feel sorry for children in daycares. A major complaint among the respondents was that these children and their parents had no family time together. Another claim was that daylong daycare given by someone other than the child's mother destroys the parent-child relationship and tires out the children. Claims were made, that parents should spend time with their children. Nevertheless, some of the respondents claimed that their attitude toward non-maternal daycare for young children was also influenced by whether the parents needed this care in order to go to work and support their families. The researchers provided a number of explanations for the students' negative responses, among them, negative personal experiences with their own families when they were young, stories they heard about low quality care at daycare centers and their own bad experiences with such settings. The study also found that young women who are not yet mothers had stronger and more negative feelings about non-maternal care than the other respondents did. According to the research participants (Ailwood \& Boyd, 2006), it is necessary to focus the teacher-training program for preschoolers and designate specific training, separate and longer for children from birth to age three. This separation will give a better understanding of theoretical and practical aspect, and will provide practical tools and ways of working with children ages birth to three, 
such as developmental delay, boundaries, psychology courses on subjects like temperament and emotional aspects alongside courses in team management and working with parents. The findings highlight the importance and the urgent need to raise the prestige and importance of training teachers for children from birth to age three.

As of today, most students who graduate with a bachelor's degree in early childhood education do not work in daycare centers, but rather in the public kindergartens for children aged 3-6, that are under the supervision of the Ministry of Education. The main reasons are the low salaries paid to caregivers in the daycare centers, the low educational level of the daycare center staff, the long work hours, the lack of Ministry of Education supervision in these settings, and the prevailing public view that the role of the daycare center staff is to provide care rather than to educate. Clearly, there is a gap between the critical significance of the first three years of life in child development and the quality of the investment made in caring for and educating children in this age group.

\section{Research Context}

The current study is of great significance, especially in light of the scarcity of studies examining the perceptions and attitudes of early childhood education students regarding the care and education of young children and the relatively new programs designed to qualify students as teachers for this age group.

As noted, in 2006 the Council for Higher Education approved a new outline for training teachers based upon the Ariav Committee. Teaching certificates issued according to this new outline, authorize teachers to work with children aged 0-6. Introducing this change will have an impact on the educational system with respect to the birth-to-three age group, ranging from early identification of children at risk through the construction of developmentally appropriate programs of study, enhancement of the research spectrum and increased professionalism among early childhood caregivers. Implementation of the Ariav plan in early childhood has meant that the entire system involved in training people to work with this age group must learn about this topic and become involved in educational practice in daycare and family care settings. It also has had an impact on students of education majoring in preschool education at teacher education colleges. Today students are required to observe and interact with young children and to reflect upon, analyze and plan activities for young children while at the same time anchoring their understanding in theory and in research. They must cope with and be open to educational issues unique to these young ages. In addition, they must analyze these issues to learn about themselves and the children. In this way, they receive tools that are appropriate for working with young children.

The current study focuses on examining the folk psychology \& pedagogy of early childhood education students with respect to education and care during the first three years of life. It examines the views they bring with them to their studies as well as the ways in which these views change during the course of their education.

\section{Research Questions}

What is the folk psychology \& pedagogy of early childhood education students with respect to education and care during the first three years of life at the beginning of their training? How do these views change during the course of their formal education?

It is important to note that in this study, we examine whether the courses learned led to a change in perceptions of students. We did not examine the cultural differences between students and did not examine different ages of students as an independent variable.

\section{Method}

\subsection{Research Design}

The current study is a developmental research study. It uses the quantitative approach based on a questionnaire formulated for the purpose of the study. The research is designed to compare perceptions of the birth-to-three age group among students at the beginning of their education to those of students at the end of their college studies. The research data were gathered at one point in time in reference to students at two different stages of their training (cross-sectional design). This design was chosen to revoke the possibility of developmental changes that may jeopardize the validity of the study in a longitudinal design (such as curricular changes).

\subsection{Basic Assumptions}

1. Students who are training to become teachers have a folk psychology \& pedagogy worldview regarding the type of education children from birth to age three require.

2. Students who are training to become teachers have varying levels of awareness regarding the type of education children from birth to age three require. 


\subsection{Research Population and Process}

Three different colleges from Israel that represent all the populations (Jewish, Arbs, religious and secular) from the north, south and the center of the country were chosen for this research. These colleges develop programs for early childhood education. All The information used in this research was collected during the classes; all the students could refuse to submit the questionnaire. However, we found that all of them wanted to participate. All the teachers that collected the date received instructions regarding how to forward the questionnaire. The teachers explained to the students that the researchers wanted to observe their perceptions about care and education of children from birth to age three. It is important to mention that in The Arab College the questionnaires were translated into Arabic and then translated back from Arabic to Hebrew in order to make sure that the questions are the same in both languages. The research population comprised of 379 students of education majoring in early childhood education in three colleges in Israel. There were 187 of these students who were in their first year of studies and 192 in their third and final year.

Out of these students ( $\mathrm{n}=379), 188$ (49 percent) represent those being trained to work in the Jewish secular sector, 119 (32 percent) represent those being trained to work in the Arab sector and 72 (19 percent) represent those being trained to work in the Jewish religious sector.

The distribution of frequencies of the sample characteristics is as follows: the sample comprises of 100 percent women, 35 percent of them are single and 65 percent are married. Their average age is 23.94 (SD 4.01). Thirty three percent of the research participants define themselves as secular, 41 percent as traditional, 25 percent as religious and 1 percent as ultra-orthodox. Sixty five percent of the participants have prior experience in working with young children; while 35 percent have no prior experience in working with this age group.

\subsection{Research Tool}

A structured questionnaire was constructed for this study aimed at examining the perceptions of early childhood education students regarding different aspects in the education and care of children from birth to age three. The questionnaire was constructed based upon several sources: knowledge obtained from the literature; the accepted curricula in psychology and didactics in colleges in Israel with respect to the birth-to-three age group; and the professional experience of a team of experts in early childhood. The team members included two experts in early childhood education, an expert in motor development in early childhood and a psychologist.

The questionnaire was divided into two parts. The first part included personal attributes, as outlined in the above section describing the research population. The second part of the questionnaire contained five domains of reference:

1. Perceptions regarding the impact of age on child development. The respondents were asked to choose one of two options: (a) The first year of life is the most important; (b) There is no difference between the first three years of life.

2. Perceptions regarding domains that affect child development. The respondents were shown statements describing the effect of four domains of child development:

(1) physical (e.g., Children have motor needs, such as adapting the space to motor responses); (2) social (e.g., Children need contact with other children); (3) emotional (e.g., Children need warmth and tenderness); and, (4) cognitive (e.g., Children need different forms of enrichment). The respondents were asked to indicate the extent of their agreement with each of these statements on a five-point scale. The Cronbach's alpha reliability coefficients calculated for each of the four domains were all higher than 0.70 .

3. Perceptions regarding care and educational settings that contributed to child development from birth to age three. To examine the influence of the setting (nanny, family care setting or daycare center) in various domains, the respondents were asked to indicate which setting they believed had the greatest influence on child development. They were then asked to indicate the effect of this setting in three domains: emotional, social and cognitive. The Cronbach's alpha reliability coefficients calculated for each of these domains were as follows: 0.77 for the emotional domain, 0.67 for the social domain and 0.76 for the cognitive domain. For each domain, an average effect of the setting was calculated.

4. Desirable perceptions regarding care and educational methods from birth to age three. The questionnaire included nine ways of coping with distress among children. The respondents were asked to rank the effectiveness of each of these coping methods. An exploratory factor analysis with orthogonal rotation was conducted in an attempt to identify patterns of coping with distress among children. This analysis yielded three factors that together explain 64 percent of the variance, as depicted in Table 1. 
Table 1. Results of factor analysis of coping methods $(\mathrm{N}=379)$

\begin{tabular}{|c|c|c|c|}
\hline & \multicolumn{2}{|c|}{ Loadings } & \multirow[b]{2}{*}{ Third Factor } \\
\hline & First Factor & Second Factor & \\
\hline Removal & .774 & -.195 & .160 \\
\hline Demand to stop the behavior & .753 & .279 & \\
\hline Censure & .684 & & -.177 \\
\hline Punishment & .662 & -.232 & .159 \\
\hline Calming words & & .792 & \\
\hline Calming touch & & .701 & .160 \\
\hline Emotional reflection & & & .786 \\
\hline Behavioral reflection & & .106 & .734 \\
\hline
\end{tabular}

According to Table 1, the first factor stresses strictness in coping with the child, the second factor stresses calming means of coping and the third factor stresses reflection on and awareness of the child's behavior. Based on the results of the analysis, we calculated three measures, by the average use of each of the means included in the pattern. A high score indicates that the coping strategy is used largely.

5. Perceptions regarding the most important role in caring for children from birth to age three. The respondents were asked to rank statements describing the various roles of caregivers/educators. An exploratory factor analysis with orthogonal rotation was conducted to identify general categories of roles. The analysis yielded two factors that together explain 66 percent of the variance, as shown in Table 2.

Table 2. Results of factor analysis of roles in childcare $(\mathrm{N}=379)$

\begin{tabular}{lll}
\hline & \multicolumn{2}{c}{ Loading } \\
& .774 & -.170 \\
\hline Meeting the child's needs & .761 & \\
The child's well-being & .725 & \\
Playing with the child & .673 & .225 \\
Encouraging social interaction & .584 & .262 \\
Regulating emotions & .374 & -.370 \\
Inclusion of the child & & .784 \\
Preparing the child for educational settings & .444 & .498 \\
Imparting new knowledge & Second Factor \\
\hline
\end{tabular}

In Table 2, the role of the caregiver is characterized by the two dimensions of child enrichment and child well-being. Child enrichment includes imparting new knowledge and preparation for educational settings. Child well-being includes meeting the child's needs, playing with him, encouraging him and regulating his emotions. Based on the results of the analysis, we calculated two measures, by the average of the answers given for all the roles included in the role type. A high score indicates a high perception of the importance of the role.

The questionnaire underwent four types of content validation. First, early childhood experts joined to construct and develop the questionnaire. Second, three expert preschool teachers that work with young children were requested to read the questionnaire and give their input regarding the relevance of the content and the clarity of the statements. Third, four students were asked to complete and analyze the questionnaire: two students in their final year of studies, one first-year student at the beginning of her studies, and one teaching assistant who works with children in the birth-to-three group. These students commented about the distribution of the answers, their comprehension of the questions and the content under consideration, while making suggestions for changes in how the questionnaire was formulated. Fourth, a psychologist who is an expert in quantitative research validated the content.

\subsection{Research Procedure}

The questionnaires were distributed to first-year students at the beginning of their studies and to third or fourth year students at the end of their training. The respondents were not students of the researchers. The questionnaires were administered in a group setting during lessons that took place in the college. Participants were ensured by promising them anonymity. The number of students who were asked to participate was 404 and 379 of them completed the questionnaires.

\section{Findings}

\subsection{The Age Most Influential to Child Development}

First, we examined which year in a child's life, or in other words, which age is considered most significant to child development. The respondents were asked to select one of two options: (1) The first year of life is the most important; (2) There is no difference between the first three years of life. We calculated the frequency distribution of the answers according to year and conducted a Chi Square Test to examine the significance of the differences.

The results showed that a decided majority of the students -88 percent of those in the first year of studies and 94 
percent of those at the end of their education - believe that the first year in a child's life is the most important for his development. No significant difference was found between first-year students and those who had completed their training $\left(\mathrm{X}^{2}(1)=0.95\right.$, N.S).

\subsection{Domains Affecting Child Development}

We calculated the averages for the perceived importance of each domain and conducted a four (domain) X two (year) two-way analysis of variance, with repeated measures in the variable of domain. Figure 1 shows the averages for each of the four domains for each year.

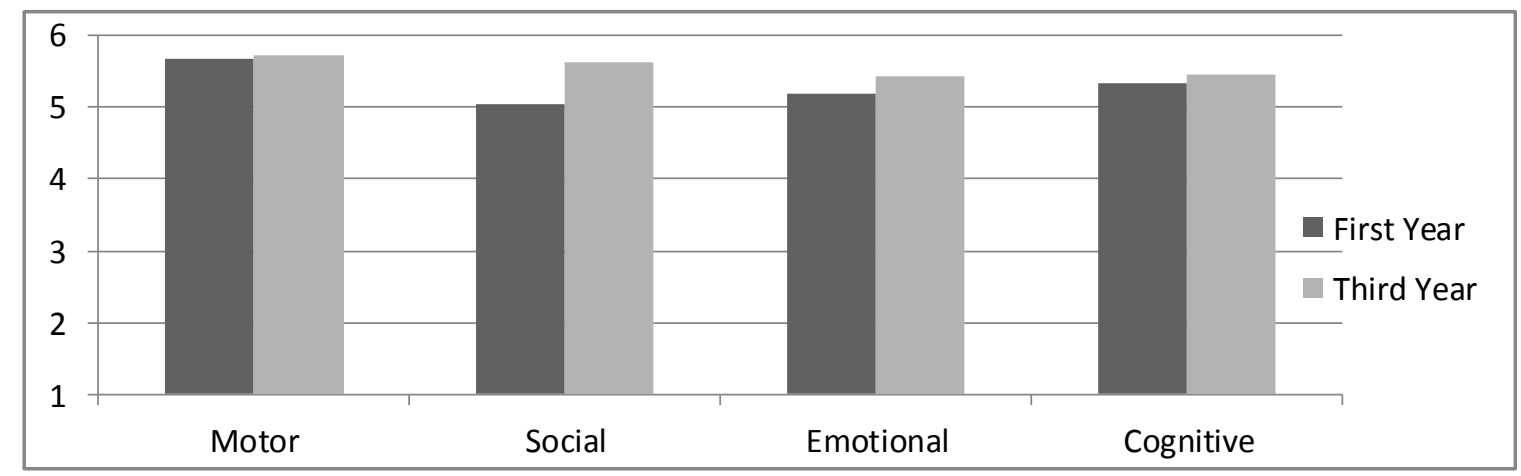

Figure 1. Perceived importance of the four domains by year-

The analysis showed a significant main effect of domain, $(F(3,278)=43.18, p<0.01)$. Bonferroni tests $(p<0.05)$ indicated that the motor domain was seen as significantly more important than all the other domains. An interaction effect was also found $(\mathrm{F}(3,278)=5.52, \mathrm{p}<0.05)$. In order to examine the interaction the two years were compared for each domain. As can be seen in the figure, a significant increase between the years was found in the importance of social domain $(\mathrm{t}(280)=3.88, \mathrm{p}<0.001)$ and the emotional domain $(\mathrm{t}(280)=3.16, \mathrm{p}<0.01)$. No significant changes were found in the motor and cognitive domains.

\subsection{Desirable Educational and Care Settings for Children from Birth to Age Three}

We examined the respondents' estimation of the influence of three setting through a three (setting) X two (year) two-way analysis of variance, with repeated measures in setting. Figure 2 shows the averages for the perceived influence of three educational settings for each year.

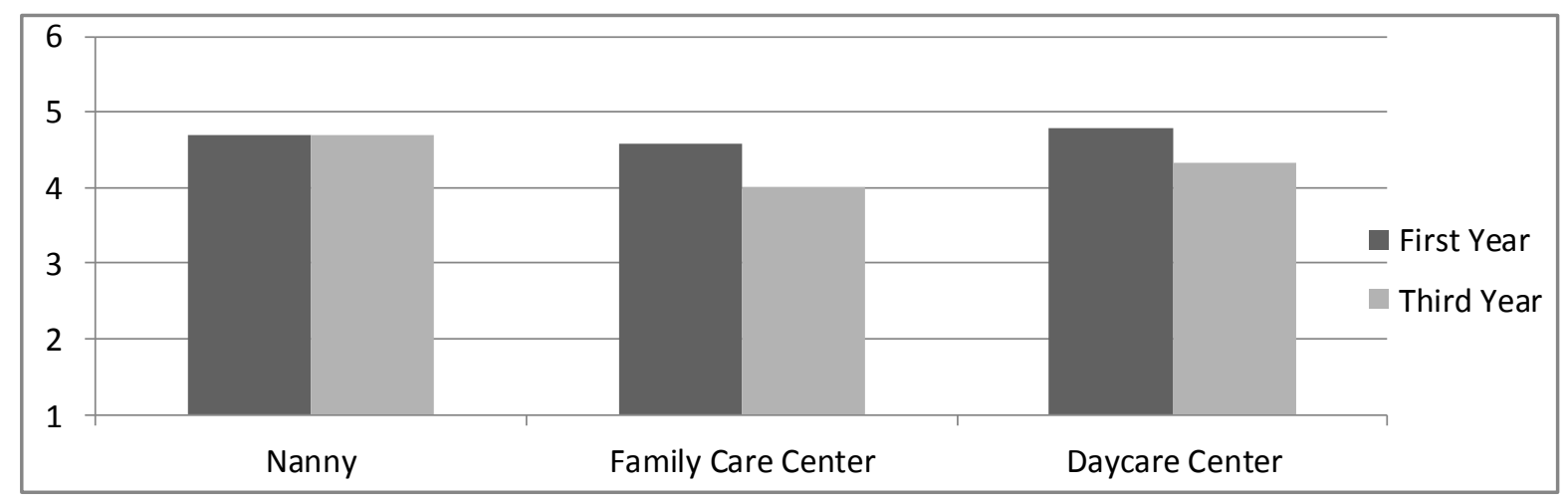

Figure 2. Perceived influence of three educational settings by year

The analysis showed a significant interaction effect $(F(3,278)=4.33, p<0.01)$. The two years were compared for each of the three settings in order to examine the interaction. A significant decrease was found in perceived importance of the daycare center $(\mathrm{t}(276)=3.17, \mathrm{p}<0.01)$ and in perceived importance of the family care setting $(\mathrm{t}(276)=3.10, \mathrm{p}<0.01)$. The perceived importance of the nanny remained high in the third year.

\subsection{Desirable Strategies of Coping with Children's Behavior from Birth to Age Three}

We conducted two-way analysis of variance, on coping strategies X year, with repeated measures in coping. Figure 3 shows the averages for the perceived effectiveness of three strategies of coping for each year. The analysis revealed a 
significant interaction effect $(\mathrm{F}(2,542)=415.81, \mathrm{p}<0.0)$. To examine the interaction, we compared students at the beginning and at the end of their training with respect to each of the three patterns. A significant increase was found in the perception of the effectiveness of awareness $(\mathrm{t}(271)=4.75, \mathrm{p}<0 . .01)$ ), along with a significant decrease $(0.05)$ in perception of the effectiveness of strictness $(\mathrm{t}(271)=1.70, \mathrm{p}<0 . .05)$. No significant change was found in the perception of the effectiveness of calming behavior $(\mathrm{t}(271)=1.39, \mathrm{p}>0.05)$.

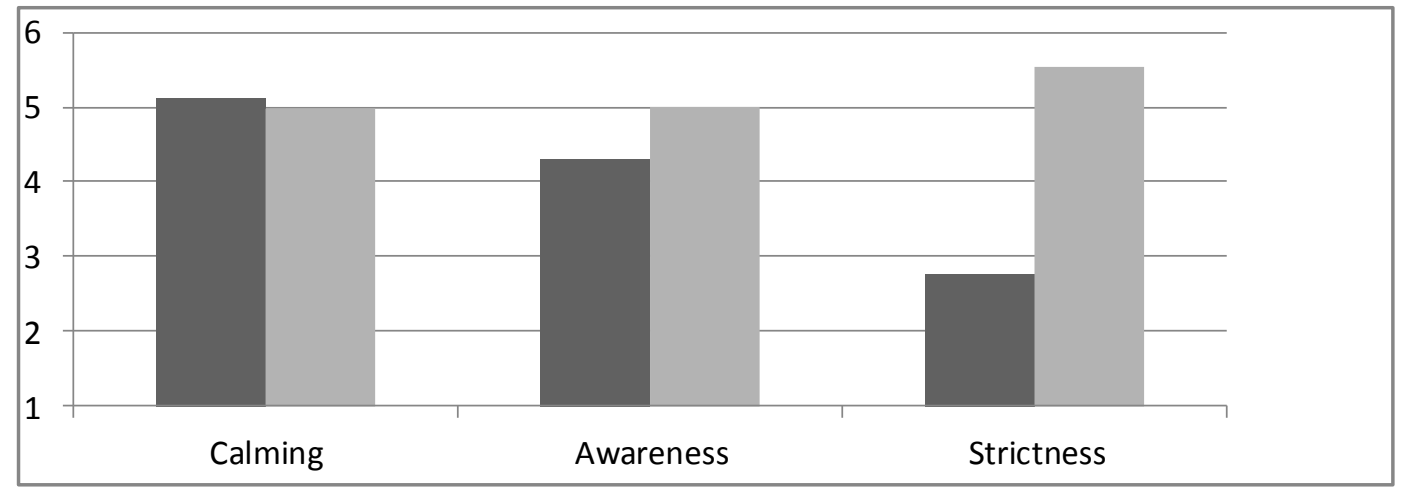

Figure 3. Desirable strategies of coping with children's behavior by year

\subsection{Most Important Role in Caring for Children from Birth to Age Three}

A two-way analysis of variance, year $\mathrm{X}$ role in caring, was conducted, with repeated measures in role. The analysis showed a significant main effect of role $(\mathrm{F}(1,273)=27.37, \mathrm{p}<0.01)$. This effect resulted from a higher perceived importance of well-being (average $=5.06, \mathrm{SD}=0.175)$ than the perceived importance of enrichment $($ average $=48.1$, $\mathrm{SD}=0.93)$. No significant effect of year was found $(\mathrm{F}(1,273)=0.03, \mathrm{p}>0.05)$. A significant effect was found for the interaction between year and role $(\mathrm{F}(1,273)=8.72, \mathrm{p}>0.01)$. Figure 4 shows the interaction.

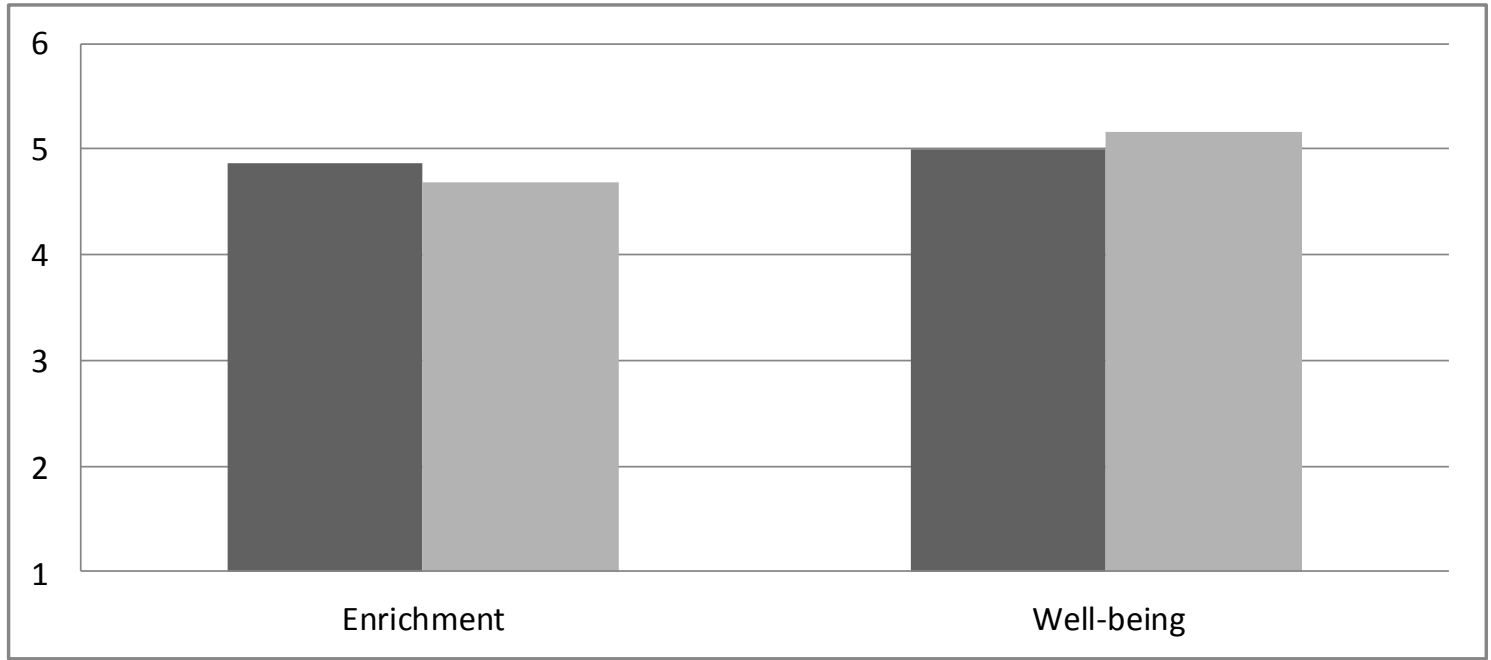

Figure 4. Perceived importance of roles, before and after training

As Figure 4 shows, the interaction emerges because the perceived importance of well-being increases during the students' training, while the perceived importance of enrichment decreases.

\section{Discussion}

The objective of this study was to examine the folk psychology \& pedagogy of students majoring in early childhood education regarding education and care for children from birth to age three and to examine changes in these views from the beginning of the students' education to the end of their studies.

The findings reveal students' folk psychology \& pedagogy perceptions about the first year in a child's life as the most important to child development, and this perception does not change during the course of their training. This finding is anchored in theories of developmental psychology and in numerous studies conducted on the importance of early experience to overall development. According to Sroufe, Cooper \& Dehart (1992), an analogy (to child development) is 
building a house. All the parts of the house are important. Without a frame, there can be no roof, and without a roof, any structure will soon deteriorate. The entire building depends on a solid foundation. Early experience determines basic social reactive and emotional regulatory patterns. Many studies and theories emphasize the power of early experience (Bowlby, 1969, 1982; Erikson, 1950; Osterweil, 1995; Rutter, 1991; Spitz, 1965; Winnicott, 1971).

Other theoretical approaches, in contrast, are supported by studies indicating that current experiences are more important than prior experiences because what is most meaningful to the child are current events and experiences that occur at present; therefore, these experiences have a bigger impact on his life in the present than his past experiences. Studies conducted in the USA, point to changes in children as a result of early intervention programs (Skeels, 1966; Van den Boom, 1989; Lieberman et.al., 1991). These studies show that early childhood education in small care centers have a crucial role in advancing children's skills and preserving their abilities for years. Early childhood education should be given to children as early in their life as possible in order to provide them with social, behavioral and educational skills, proper values infrastructure and strengthen their self-confidence. All of these elements will increase the children's chances to fulfill their abilities and natural tendencies.

The current study shows that the students' folk psychology \& pedagogy are consistent with those approaches that consider the first year of life to be most important. These perceptions did not change during the course of the students' studies. Curricula for training preschool teachers in colleges of education in Israel are cautious about adopting a deterministic approach and attribute special importance to that early experience. The period of infancy is viewed as a "sensitive" period rather than as the "decisive" period. It is important to clarify this distinction for the students and expose them to research studies and cases illustrating significant changes during the course of child development. Students should be taught that early experience does not determine the course of child development and that genuine change is always possible. Belief in the possibility for change will have a major influence on the students' desire to invest in a child and will have an impact on their motivation in working with children.

In regards to the perceived importance of the four domains to child development, it was found that the students at the beginning and at the end of their studies see the motor domain as being most important to child development. The social domain is considered the least important at the beginning of their studies, but its importance increases as their training continues. It is important to note that this division is designed in order to simplify understanding and focus on processes that are complex and intertwined. In this sense, no one domain is more important than another is. A child is a single entity, and his/her behavior is the result of a complex of psychological processes that influence one another. Thus, all developmental aspects must be considered, as well as the interactions among them. Moreover, it is extremely difficult to distinguish between the intermingled social and emotional aspects.

The findings reveal a change in the way students perceive the relative importance of the different spheres from the time they begin their studies to the time they almost graduate. At the outset, the students make a clear differentiation, which stresses the importance of the physical sphere and diminishes the importance of the social sphere. By the end of training, all four spheres are perceived as equally important. This change indicates that the students have internalized the messages they have been exposed to during their training regarding the integrative nature of the different spheres of development.

In reference to care settings, we found that the students perceive the caregiver as having a major influence on child development, and this perception does not change from the beginning of their studies to the time nearing graduation. In contrast, the perceived degree to which family care centers and daycare centers influence child development decreases between the beginning and the end of their studies.

The finding that a nanny/caregiver is preferable in caring for young children is not surprising. For years, the research literature (Bowlby, 1982; Winnicott, 1971) has justified choosing one supervising adult as the best alternative for caring for babies and young children. Current studies and theories show that the most important factor influencing children's emotional, social and cognitive development is the emotional treatment provided by the caregiver is individual care at home, whether given by the father, the grandmother or a nanny. This is followed by care provided in a family care setting, where babies were found to receive warmer treatment than in daycare centers, where the treatment was found to be the least warm and responsive (Koren-Karie \& Sagi, 2000; Sagi et.al., 2002).

This finding is reinforced by a study that examined children's stress levels in various educational institutions and care settings. The study found that the level of the anxiety hormone Cortisol among children in family care and daycare settings rose during the time they spent in group care compared to children who were cared for individually at home (Gunnar, Kryzer, Van Ryzin \& Phillips, 2010; Watamura, Donzella, Alwin \& Gunnar, 2004). This was the case whether the child was cared for by the mother or by any other person replacing her.

The decline in students' perceptions of family care and daycare settings during the course of their studies can be explained by the students' experience in these settings during their training. The students stated that they believed that 
the staff is not sufficiently professional and that the number of caregivers is not adequate to meet the needs of such young children. In this case, the emphasis is not on the setting but rather on the quality of the care. The students may have found the professional level at the family care and daycare settings in need of improvement, primarily due to the limited number of staff members and the long time children must wait for someone to respond, play with them and be emotionally involved with them. This finding indicates that the first three years of a child's life being cared for in high quality and professional daycare settings are of major importance to young children.

The finding regarding the importance of role in caring for children from birth to age three, show that the perceived importance of wellbeing components of childcare/education, (such as playing, meeting needs, regulating emotions, enabling the child), increases in significance during the course of the students' training. Whereas the perceived importance of enrichment components, (such as acquiring new knowledge, enriching language and preparing the children for school), decreases.

The rise in the students' understanding of the children's wellbeing is not surprising. In effect, wellbeing is the basis for optimal growth and the primary objective of early childhood education and care. An interesting and surprising finding was the decline in students' perceptions of the importance of enrichment from the beginning to the end of their training. Is enrichment during early childhood perceived to be of no importance? This parameter should also be expected to rise during the course of the students' education. Furthermore, the quality of childcare beyond providing the child's physical and emotional needs is found in advancing the child's cognitive development. The increase in the importance of wellbeing "at the expense" of the cognitive enrichment can be explained by the training program applied by the colleges that participated in this research. These programs stress the traditional theories of the emotional-social aspect of development (i.e. wellbeing) and less attention is given to the cognitive aspect.

Finally, the finding regarding the students' perceptions of coping strategies to deal with distress, frustration and difficulties changed from the time they began their studies to the time of near graduation. A significant increase was found in perceived effectiveness of coping through awareness along with a significant decrease in perceived effectiveness of strict coping methods. Thus, the desired strategies change in the course of training from employing strict methods to providing explanations and repeated opportunities for behavioral change. This change in the students' perceptions is in line with currently prevalent professional views regarding means of coping with distress among children. The change indicates that the students have internalized these messages during their studies.

Many studies have demonstrated that the punishment perspective is based upon an illusion. Even if the disruptive behavior ceased, it is likely that even worse behavior will eventually emerge (Sroufe, Cooper, \& Dehart, 1992; Winnicott, 1971).

During their studies, the students learn that children's problematic and distressful behavior should be coped with by offering explanations, guidance and opportunities. Moreover, preschool education today reflects current social views regarding children's rights. Corporal punishment, or any other form of derogatory punishment, breaches children's fundamental human rights of respect for human dignity, physical integrity and equal protection under the law. Every child has the right to receive proper attention. This right includes the right to be raised and educated without violence in a manner that is based on love, affection, mutual understanding, respect, and solidarity (Morag, 1998; Shavit, 1996).

The quantitative approach taken in the current study has made it possible to map the folk psychology \& pedagogy of students majoring in early childhood education and identify the changes taking place over the course of their studies. Yet the quantitative method is also the source of the study's limitations. This approach makes it impossible to identify what components of the course of the studies led to the changes that took place (such as theoretical lectures and practical experience) and how these components shaped the new perceptions. Therefore, there is a need of a future research that would take a qualitative approach and could shed light on this question. This should be a qualitative study to examine in depth perceptions regarding children aged birth to three. It is recommended that it would include interviews with students, teachers and policy makers of early childhood about the curriculum and possible directions for improvement. It should also observe different cultures, religious and secular Arabs and their perception regarding early childhood education program, and of course, a comparison of Israeli study programs to those of other countries.

\subsection{Research Implications}

Building a special training framework that trains caregivers of children aged birth to three may greatly promote the professional status of those who practice early education. A high level of training, one that is focused on a certain age and deeply understands the complex role of care and education from birth to age three, will help build a professional identity in regards to this profession. This identity is developed in early stages of training (Weis \& Fisherman, 2011) and that is why it is important to deal with it in training students of early childhood education. Many studies show that the beginning stages in becoming a teacher are the most significant stages in the kindergarten teacher's professional development (Feiman-Nemser, 2003; Kagan, 1992; Kagan \& Klein, 1973). 
Specific training for these ages will better the perception of the public on the profession and will influence the child, the family and society as a whole. This will help better learning and practicing education in these ages, and daycare centers and kindergartens will be able to provide young children what they need for proper development.

This study contributes to the understanding of the preparation of the early childhood caregiver in Israel. It encourages broader thinking about the education and care of children from birth to age three especially with respect to in-training programs for educators of children from birth to age three. We recommend that first and prior to the learning process, the students' folk psychology and pedagogy is exposed. Learning process today are considered not only in terms of acquiring knowledge from the outside but also as an internal dialogic process. Active learning facilitates constructing worldviews and positive attitudes toward the other and toward the subject that is being learned. We further recommend that training programs in early childhood education in societies stress three main points: 1) Larger emphasis on the role of the caregiver during the first year of the child's life as essential and important to the child's ongoing development, however, while still recognizing the importance of other development stages; 2) Strive for a proper educational settings which will meet the children's needs and employ the child as an individual and fulfill his needs; 3) Meeting children's physical needs in addition to their emotional needs. Physical connection, maintaining eye contact, tenderness and conversing while meeting their physical needs will help build an initial image that will form the basis of their future self-image.

\section{Acknowledgments}

The research reported in this paper is as a part of a wide-ranging collaborative research study conducted by a team of research colleagues, including the authors of this paper. The authors extend thanks to Dr. Ester Robin, Dr. Ibtisam Marey-Sarwan, Dr. Ora Segal-Drori and Zohara Shifrin for their assistance in collecting data.

\section{References}

Ailwood, J., \& Boyd, W. (2006). First year early childhood education students' beliefs about children in long day childcare. Proceedings of the Australian Teacher Education Association. Fremantle, Australia.

Ariav, T. (2007). Guidelines for teacher training in institutions of higher education in Israel. Report of the Ariav Committee. Jerusalem: Council for Higher Education [in Hebrew].

Bowlby, J. (1969/1982). Attachment and loss. New York: Basic Books.

Campbell, F. A., Pungello, E. P., Miller-Johnson, S., Burchinal, M., \& Ramey, C. T. (2001). The development of cognitive and academic abilities: Growth curves from an early childhood educational experiment. Developmental Psychology, 37, 231-242. https://doi.org/10.1037/0012-1649.37.2.231

Central Bureau of Statistics (2010). Israel in numbers (Education, p. 14). Jerusalem: Central Bureau of Statistics [in Hebrew].

Chetty, R., Friedman, J. N., Hilger, N., Saez, E., Schanzebbach, D. W., \& Yagan, D. (2010). How does your kindergarten classroom affect your earnings? Evidence from project star. NBER working Paper No. 16381. http://ssrn.com/abstract=1683131. Accessed November 9, 2010. https://doi.org/10.3386/w16381

Cochran-Smith, M., \& Villegas, M. (2015). Framing teacher preparation research: An overview of the field, Part I. Journal of Teacher Education 66(1), 7-20. https://doi.org/10.1177/0022487114549072

Cochran-Smith, M., Villegas, M., Abrams, L., Chavez-Moreno, L., Mills, T., \& Stern, R., (2015). Critiquing teacher preparation research: An overview of the field, Part II. Journal of Teacher Education, 66(2), 109-121. https://doi.org/10.1177/0022487114558268

Darling-Hammond, L., \& Haertel, E. (2012). A better way to grade teachers. Los Angeles Times. Retrieved from http://www.latimes.com/news/opinion/commentary/la-oe-darling-teacher.

Darling-Hammond, L., Wei, R. C., \& Johnson, C. M. (2009). Teacher preparation and teacher learning: A changing policy landscape. In G. Sykes, B. L. Schneider, \& D. N. Plank (Eds.), Handbook of Education Policy Research (pp. 613- 636). New York: American Educational Research Association and Routledge.

Dayan, Y. (2006). Training an educational-care staff for early childhood educational settings - A standards document. Jerusalem: The Hebrew University [in Hebrew].

Decker, L. E., \& Rimm-Kaufman, S. E. (2005). Personality characteristics and teachers' beliefs among pre-service teachers. Unpublished Manuscript.

DeSchipper, E. J., Riksen-Walraven, J. M., \& Geurts, S. A. (2006). Effects of child- caregiver ratios on the interactions between caregivers and children in child-care centers: An experimental study. Child Development, 77, 861-874. https://doi.org/10.1111/j.1467-8624.2006.00907.x 
Deynoot-Schaub, M., \& Riksen-Walraven, J. M. (2005). Child care under pressure: The quality of Dutch centers in 1995 and in 2001. The Journal of Genetic Psychology, 166(3), 280-296. https://doi.org/10.3200/GNTP.166.3.280-296

Erikson, E. H. (1950). Childhood and Society. New York: W.W. Norton.

Espanioly, N. (2015). Early childhood in the Arab and Palestinian people in Israel. In G. Russo-Zimet, M. Ziv, \& A. Masarwah-Srour (Eds.), Childhood in Arab Society in Israel (pp. 29-58). Tel-Aviv: Mofet Institute \& Al Qasemi Academic College of Education: [in Hebrew].

Feiman-Nemser, S. (2003). What new teachers need to learn. Educational Leadership, 60(8), 25-30.

Gunnar, M. R., Kryzer, E., Van Ryzin, M. J., \& Phillips, D. A. (2010). The rise in cortisol in family day care associations with aspects of care quality, child behavior and child sex. Child Development, 81, 851-809. https://doi.org/10.1111/j.1467-8624.2010.01438.x

Ispa, J. M. (1995). Ideas about infant and toddler care among Russian child care teachers, mothers, and university students. Early Childhood Research Quarterly, 10, 359-379. https://doi.org/10.1016/0885-2006(95)90012-8

Johansson, E., Cobb-Moore, C., Lunn-Brownlee, J., Walker, S., Boulton-Lewis, G., \& Ailwood, J. (2014). Children's perspectives on values and rules in Australian early education. Australasian Journal of Early Childhood, 39(2), $12-20$.

Kagan, D. M. (1992). Professional growth among pre-service and beginning teachers. Review of Educational Research, 62, 129-169. https://doi.org/10.3102/00346543062002129

Kagan, J., \& Klein, R. E. (1973). Cross-cultural perspectives on early development. American Psychologist, 28(11), 947-961. https://doi.org/10.1037/h0035556

Kitayama, S., \& Cohen, D. (Eds.) (2010). Handbook of cultural psychology. New York, NY: The Guilford Press.

Klein, P. S. (2008). From Research to Practice in Early Childhood Education. Jerusalem: The Israel Academy of Sciences and Humanities [in Hebrew].

Koren-Karie, N., \& Sagi, A. (2000). Parental dilemmas during infancy: Going to work and choosing a non-maternal framework for infants. In P. Klein (Ed.), Parents, infants, toddlers and caregivers: Studies on child development in Israel. Even Yehuda: Reches Publishing House [in Hebrew].

La Paro, K. M., Siepak, K., \& Scott-Little, C. (2009). Assessing beliefs of pre-service early childhood education teachers using Q-sort methodology. Journal of Early Childhood Teacher Education, 30, 22-36. https://doi.org/10.1080/10901020802667805

Lee, K., \& Johnson, A. S. (2007). Child development in cultural contexts: Implication of cultural psychology for early childhood teacher education. Early Childhood Teacher Education 35, 233-243. https://doi.org/10.1007/s10643-007-0202-7

Lieberman, A. F., Weston, D. R., \& Pawl, J. H. (1991). Preventive intervention and outcome with anxiously attached dyads. Child Development, 6, 199-209. https://doi.org/10.2307/1130715

Lunn-Brownlee, J., Johansson, E., Cobb-Moore, C., Boulton-Lewis, G., Walker, S., \& Ailwood, J. (2013). Epistemic beliefs and beliefs about teaching practices for moral learning in the early years of school: Relationships and complexities. Education 3(13), 1-20. http://eprints.qut.edu.au/58677/c

McCormick, M. C., Brooks-Gunn, J., Buka, S. L., Goldman, J., Yu, J., Salganik, M., ‥ Casey, P. H. (2006). Early intervention in low birth weight premature infants: Results at 18 years of age for the infant health and development program. Pediatrics, 117, 771-780. https://doi.org/10.1542/peds.2005-1316

Morag, T. (1998). Children's rights and the law. In: Y. Kadmon \& G. Efrat (Eds.), Children's Rights in Israel: A collection of articles and sources. Jerusalem: The National Council for the Child, 14-24 [in Hebrew].

Mustard, J. F. (2007). Experience-based brain development: Scientific underpinning of the importance of early child development in a global world. In M. E. Young \& L. M. Richardson (Eds.), Early child development from measurement to action: A priority for growth (pp. 43-84). Washington, D.C.: The World Bank.

NICHD-The Effects of Infant Child Care on Infant-Mother Attachment Security: Results of the NICHD Study of Early Child Care NICHD Early Child Care Research Network. NICHD Early Child Care Research Network. Article first published online: $30 \mathrm{JUN}$ 2006. http://onlinelibrary.wiley.com/doi/10.1111/j.1467-8624.1997.tb01967.x/abstract

Olson, D. R., \& Bruner, J. S. (1996). Folk psychology and folk pedagogy. In: D. Olson \& N. Torrance (Eds.), Handbook of Education in Human Development (pp. 9-27). Oxford: Blackwell. 
Osterweil, Z. (1995). Open solutions. Jerusalem and Tel Aviv: Schocken [in Hebrew].

Ramey, C. T., \& Ramey, S. L. (2004). Early learning and school readiness: Can early intervention make a difference? Merrill Palmer Quarterly, 50, 471-491. https://doi.org/10.1353/mpq.2004.0034

Rimm-Kaufman, S. E., Storm, M. D., Sawyer, B. E., Pianta, R. C., \& La Paro, K. M. (2006). The teacher belief q-sort: A measure of teachers' priorities in relation to disciplinary practices, teaching practices and beliefs about children. Journal of School Psychology, 44, 141-165. https://doi.org/10.1016/j.jsp.2006.01.003

Rosenthal, M. (2004). Spotlights: Social policy and quality of education and care in preschool educational settings. Jerusalem: The Hebrew University [in Hebrew].

Rosenthal, M. (2009). Committee report: Standards for operating educational settings for young children. Jerusalem: Ministry of Industry, Trade and Labor and Division of Education and Care Centers for Young Children [in Hebrew].

Rutter, M. (1991). Nature, nurture and psychopathology: A new look at an old topic. Development and Psychopathology, 3, 13-125. https://doi.org/10.1017/S0954579400000031

Sagi, A., Koren-Karie, N., Gini, M., Ziv, Y., \& Joels, T. (2002). Shedding further light on the effects of various types and quality of early child care on infant-mother attachment relationship: The Haifa study of early child care. Child Development, 73, 1166-1186. https://doi.org/10.1111/1467-8624.00465

Schweinhart, L. J., \& Fulcher-Dawson, R. (2009). Early childhood education. In G. Sykes, B. Schneider \& D. N. Plank (Eds.), Handbook of Education Policy Research (pp. 876-888). AERA-American Educational Research Association. New York, NY: Routledge.

Shavit, Z. (1996). Children's tales: Introduction to the Poetics of Children's Literature. Tel Aviv: Am Oved [in Hebrew].

Skeels, H. M. (1966). Adult status of children with contrasting early life experience: A follow-up study. Monographs of the Society for Research in Child Development, 31(3), 1-65. https://doi.org/10.2307/1165791

Spitz, R. A. (1965). The first year of life. A psychoanalytic study of normal and deviant development of object relations. New York: International Universities.

Sroufe, A., Cooper, R., \& Dehart, G. (1992). Child development: Its nature and course. (2nd Ed.). New York: McGraw Hill.

Susman-Stillman, A., Pleuss, J., \& Englund, M. (2013). Attitudes and beliefs of family- and center-based child care providers predict differences in caregiving behavior over time. Early Childhood Research Quarterly, 28(4), 905-917. https://doi.org/10.1016/j.ecresq.2013.04.003

Taguma, M., Litjens, I., \& Makowiecki, K. (2012). Quality matters in Early Childhood education and care: Finland, published on the responsibility of the Secretary-General of the OECD [Electronic version]. http://www.oecd.org/edu/school/49985030.pdf

The Dovrat Commission Report (2005). The National Task Force for the Advancement of Education in Israel - The National Education Program [in Hebrew].

Theobald, M., Danby, S., \& Ailwood, J. (2011). Child participation in the early years: Challenges for education. Australasian Journal of Early Childhood, 36(3), 19-26

Thorpe, K., Ailwood, J., Brownlee, J., \& Boyd, W. (2011). Who Wants to Work in childcare? Pre-service early childhood teachers' consideration of work in the childcare sector. Australasian Journal of Early Childhood, 36(1), 85-94.

Trajtenberg, M. (2011). Report of the committee for socioecononic change. Jerusalem: Office of the Prime Minister [in Hebrew].

Tzaban, H. (2012). Mapping the players in the pre-elementary educational system in Israel. In A. Kimhi (Ed.), Pre-elementary education in Israel: Organizational and Demographic Aspects (pp. 25-58). Jerusalem: Taub Center for Social Policy Studies in Israel [in Hebrew].

Van den Boom, D. C. (1989). Neonatal irritability and development of attachment. In G. Kohnstamm (Ed.), Temperament in Childhood (pp. 299-318). New York: Wiley.

Watamura, S. E., Donzella, B., Alwin, J., \& Gunnar, M. R. (2004). Morning to afternoon increases in cortisol concentrations for infants and toddlers at child care: Age differences and behavioral correlates. Child Development, 74, 1006-1020. https://doi.org/10.1111/1467-8624.00583 
Watamura, S. E., Phillips, D. A., Morrissey, T. W., McCartney, K., \& Bub, K. (2011). Double jeopardy: Poorer social-emotional outcomes for children in the NICHD SECCYD experiencing home and child-care environments that confer risk. Child Development, 82(1), 48-65. https://doi.org/10.1111/j.1467-8624.2010.01540.x

Weiss, I., \& Fisherman, S. (2011). Cognitive and personality factors in teachers training: Comparison of college to university students. Curriculum and Teaching, 26(1) 33-55. https://doi.org/10.7459/ct/26.1.03

Winnicott, D. (1971). Playing and reality. Great Britain: Routledge.

\section{Copyrights}

Copyright for this article is retained by the author(s), with first publication rights granted to the journal.

This is an open-access article distributed under the terms and conditions of the Creative Commons Attribution license which permits unrestricted use, distribution, and reproduction in any medium, provided the original work is properly cited. 